\title{
AKTUALISASI BUDAYA INOVASI PADA ORGANISASI SEKTOR PUBLIK
}

\section{INNOVATION CULTURE ACTUALIZATION IN PUBLIC SECTOR ORGANIZATIONS}

\author{
Kemal Hidayah, Mayahayati Kusumaningrum, Fani Heru Wismono, dan \\ Rustan Amarullah \\ Pusat Kajian dan Pendidikan dan Pelatihan Aparatur III \\ Lembaga Administrasi Negara (PKP2A III LAN) \\ Jl. H.M. Ardans (Ring Road III) Samarinda-Kalimantan Timur \\ Email : hidayahkemall@gmail.com; may.kaltim@gmail.com
}

Naskah diterima: 27 Agustus 2018; revisi terakhir: 22 Oktober 2018; disetujui: 9 November 2018

\begin{abstract}
Innovation is the key to improve organizational performance. The development presently requires the actualization of innovation culture as a continuous improvement in the organizations' services. This paper presents an overview of the application of innovation culture in public sector organizations namely Investment and Integrated Licensing Offices (DPMPTSP) of Samarinda City, as well as factors that influence the success of actualizing the culture of innovation in this organization. This research is a qualitative research with a descriptive approach. The application of an innovation culture in DPMPTSP of Samarinda City has been relatively optimal, as evidenced by the various achievements and awards that have been achieved. Afterwards, the factors that influence the success of the actualization of innovation culture in DPMPTSP of Samarinda City are mainly by visionary and innovative leadership, reliable human resources, high team collaboration, and budget support. In addition, it can also be analyzed that the innovation culture in this organization has relatively implemented a holistic model of innovation culture.
\end{abstract}

Keywords : Innovation, Innovation Culture, Organization, Public Service 


\begin{abstract}
Abstrak
Inovasi merupakan kunci untuk meningkatkan performa organisasi. Perkembangan zaman menuntut aktualisasi atas budaya inovasi sebagai perbaikan terus menerus atas pelayanan organisasi yang ada. Tulisan ini menyajikan gambaran mengenai penerapan budaya inovasi dalam organisasi sektor publik yakni DPMPTSP Kota Samarinda, serta faktor-faktor apa saja yang mempengaruhi keberhasilan aktualisasi budaya inovasi dalam organisasi tersebut. Penelitian ini merupakan penelitian kualitatif dengan pendekatan deskriptif. Hasil penelitian ini menunjukkan bahwa penerapan budaya inovasi di DPMPTSP Kota Samarinda relatif sudah berjalan optimal, terbukti dengan berbagai capaian dan penghargaan yang telah dihasilkan. Adapun faktor-faktor yang mempengaruhi keberhasilan aktualisasi budaya inovasi di DPMPTSP Kota Samarinda utamanya adalah kepemimpinan visioner dan inovatif, sumberdaya manusia yang handal, kerjasama tim yang tinggi, dan dukungan anggaran. Selain itu, juga dapat dianalisis bahwa budaya inovasi pada organisasi ini relatif sudah menerapkan model holistik budaya inovasi.
\end{abstract}

Kata Kunci : Inovasi, Organisasi, Budaya Inovasi, Pelayanan Publik

\title{
A. PENDAHULUAN
}

Kinerja unit pelayanan publik saat ini sudah mulai menunjukkan "citra" yang positif meskipun belum merata terlihat pada seluruh level pemerintahan daerah yang ada, namun upaya-upaya perbaikan birokrasi ke arah atau capaian positif tersebut sudah demikian nyata terlihat. Gelombang reformasi birokrasi yang hingga kini digaungkan serta tantangan mewujudkan Birokrasi 4.0 menjadi dorongan bagi sektor publik untuk segera mengakselerasi business-process nya melalui berbagai inovasi.

Urgensi penerapan inovasi dalam proses kerja organisasi sektor publik disampaikan langsung oleh Presiden Jokowi pada Rapat Koordinasi Nasional Bidang Kemaritiman di TMII, 4 Mei 2017 menyampaikan bahwa "kita terlalu rutinitas, terlalu monoton, terlalu linier, sementara dunia berubah sangat cepat. Kita harus berani meloncat”. Kemudian Wakil Presiden Jusuf Kalla dalam Rembuk Nasional Pendidikan dan kebudayaan (RNPK) Tahun 2018 mengatakan "Semua negara yang ingin sejahtera selalu menciptakan nilai tambah, dan nilai tambah tersebut bisa dicapai melalui Inovasi”. Dengan demikian, dapat diintisarikan bahwa inovasi bukan lagi menjadi sebuah opsi tetapi merupakan suatu keharusan untuk diterapkan dan dibudayakan dalam organisasi, khususnya pada sektor publik.

Meskipun demikian, Suwarno (2008:27) dalam tulisannya mengingatkan bahwa secara tradisional, sektor publik adalah sektor yang relatif tidak leluasa dalam berhubungan dengan inovasi jika dibandingkan dengan sektor private. Keengganan sektor publik dalam memanfaatkan inovasi erat kaitannya dengan sejarah dan karakteristiknya yang cenderung statis, formal, dan rigid atau dengan kata lain berkarakteristik status-quo dan tidak menyukai perubahan. Bahkan tidak hanya dalam konteks kelembagaan, secara individu pun cukup jarang inovasi menjadi bagian dari keseharian kerjanya dan hanya sebatas menjalankan tugas dan fungsinya secara business as usual.

Menyadari hal tersebut, Kementerian PAN-RB telah mencetuskan slogan "one agency one innovation" kepada seluruh birokrasi, disamping UU No. 23 Tahun 2014 tentang 
Pemerintahan Daerah juga telah mengamanatkan agar pemerintah daerah senantiasa menumbuhkan inovasi pelayanan publik. Tingginya akses informasi dan teknologi saat ini, ditambah transparansi, dan partisipasi publik secara agregat telah menciptakan tekanan tersendiri, baik secara politik maupun sosial bagi pemerintah daerah untuk menciptakan inovasi pada sektor pelayanan publiknya. Hal ini juga diungkap oleh Suwarno (2008:23) bahwa alasan bagi sektor publik untuk berinovasi lebih karena tuntutan akuntabilitas, transparansi dan berbagai prinsip good governance yang menggiring organisasi publik yang berkinerja lebih tinggi.

Beberapa pemerintah daerah melalui unit-unit pelayanan publik sudah mampu melakukan berbagai inovasi pelayanan publik, bahkan sudah menjadi "langganan" untuk studi komparasi ataupun studi tiru bagi berbagai pemerintah daerah lainnya. Objek dari studi komparasi ataupun studi tiru tersebut tidak lain adalah terobosan atau inovasi-inovasi yang sudah dilakukan oleh unit pelayanan publik tersebut dalam upaya percepatan peningkatan kualitas pelayanan publik.

Misalnya Kota Bandung dan Kota Surabaya, dua kota yang bahkan menjadi 'langganan' studi komparasi. Dalam tulisan Suhendra (2017), dijelaskan bagaimana keduanya, dalam upaya menjadi Kota Cerdas memanfaatkan berbagai inovasi TIK dalam pengelolaan pembangunan daerahnya. Kota Bandung yang fokus pada empat kerangka dasar, yakni pelayanan publik, perbaikan kinerja aparatur, membangun interaksi warga dengan pemerintah daerah, serta keterbukaan akses data. Di Surabaya, pemanfaatan IT melalui berbagai aplikasi dalam pengelolaan pembangunan daerah baik dalam perencanaan, penilaian kinerja, maupun layanan masyarakat, misalnya Surabaya Single Window (SSW), ependidikan, e-health, e-sapawarga, e-toko. Kedua kota besar ini berupaya meningkatkan pelayanan publik dengan inovasi teknologi informasi dan komunikasi (TIK). Inovasi sektor publik sebagai salah satu jalan atau bahkan breakthrough untuk mengatasi kemacetan dan kebuntuan organisasi di sektor publik, dan karakteristik dari sistem sektor publik yang cenderung status quo dicairkan melalui penularan budaya inovasi.

Terobosan yang telah dicapai serta kemampuan melahirkan dan menerapkan inovasi tersebut tentu tidak terlepas dari kapasitas organisasi tersebut untuk membuat aparaturnya termotivasi dan cukup percaya diri untuk melakukan inovasi dan mencoba hal-hal baru, selain itu, dapat dipastikan bahwa dorongan dan dukungan organisasi juga sangat tinggi terhadap kelangsungan semua praktik-praktik inovasi yang dijalankan tersebut. Oleh karena itu, diperlukan suatu pendalaman pembahasan terkait bagaimana suatu organisasi mampu dengan leluasa menstimulasi budaya berinovasi dalam organisasinya sehingga diharapkan dapat menjadi bahan anteseden atau acuan bagi organisasi sektor publik lainnya.

Dari hasil penelusuran penelitian-penelitian sebelumnya, relatif belum banyak ditemukan yang secara khusus membahas tentang budaya inovasi. Akan tetapi, lebih banyak membahas tentang pengaruh budaya organisasi yang secara positif dan signifikan terhadap kinerja organisasi (Ismail, 2008; Purba, 2009; Suryo, 2010; Trang, 2013; Logahan, 2014). Beberapa penelitian lainnya lebih banyak mendeskripsikan suatu inovasi yang dilakukan oleh instansi tertentu (Mayangsari, 2013; Fitriana, 2014) namun, belum mendalam membahas faktor utama dibalik kemunculan inovasi tersebut. Oleh karena itu, secara spesifik penelitian ini akan menganalisis faktor-faktor kunci dibalik kemunculan suatu inovasi disuatu instansi yang sudah berhasil melakukan berbagai inovasi.

Menerapkan budaya inovasi tentu akan lebih mudah jika mencontoh pada instansi yang sudah berhasil menerapkannya terlebih dahulu, dibandingkan harus secara mandiri memulai menumbuhkan budaya inovasi di dalam organisasi. Setidaknya dengan melakukan 
replikasi atau mencontoh hal-hal yang sudah mereka lakukan untuk menjalankan budaya inovasi secara berkesinambungan pada instansi yang berhasil tersebut, maka suatu organisasi hanya cukup atau tinggal melakukan hal yang sama sehingga kegagalan penerapan budaya inovasi dapat diminimalisir.

Menyoroti kesemua uraian tersebut di atas, penulis merasa perlu untuk melakukan penelitian pada suatu instansi pemerintah daerah yang dikategorikan berhasil dalam melakukan berbagai inovasi. Hal ini diperlukan agar dapat menjawab rumusan permasalahan yang ingin diketahui lebih dalam yaitu, bagaimana penerapan budaya inovasi dalam organisasi sektor publik, serta faktor-faktor apa saja yang mempengaruhi keberhasilan aktualisasi budaya inovasi dalam organisasi sektor publik?

\section{B. METODE PENELITIAN}

Penelitian ini merupakan penelitian deskriptif-kualitatif dengan menggunakan teknik pengumpulan data campuran antara in-depth interview kepada pimpinan DPMPTSP Kota Samarinda serta penyebaran daftar pertanyaan terbuka kepada seluruh pegawai DPMPTSP Kota Samarinda. Selain itu, juga dilakukan pengumpulan data dan informasi pendukung lainnya bersumber dari buku, jurnal, hasil penelitian, proceeding, serta sumber-sumber lainnya yang menunjang penelitian ini.

Fokus dan lokus penelitian ini adalah pada penerapan budaya inovasi serta faktor yang mempengaruhi keberhasilan penerapan budaya inovasi pada DPMPTSP Kota Samarinda. DPMPTSP Kota Samarinda dipilih sebagai lokus penelitian karena saat ini merupakan instansi terbaik penyedia layanan publik di lingkungan Pemerintah Kota Samarinda. Pelaksanaan penelitian ini dilakukan selama 3 (tiga) bulan yakni antara bulan Mei-Juli Tahun 2018.

\section{KERANGKAKONSEP Inovasi Sektor Publik}

Inovasi menurut Han et all (1998:33) mengacu pada produk baru atau upaya untuk melakukan terobosan-terobosan baru. Pada banyak kasus, organisasi yang kreatif dan inovatif memiliki peluang lebih besar untuk meraih sukses dibanding organisasi yang pasif dan reaktif. Cepatnya perubahan lingkungan eksternal mendorong perlunya pemahaman terhadap budaya organisasi dan eksistensi budaya organisasi yang sesuai (Rediyono dan Ujianto, 2013:103).

Sektor publik memerlukan inovasi untuk memenuhi kebutuhan masyarakat secara umum. Dalam prakteknya, sektor publik berinovasi bukan dalam rangka survival, namun lebih untuk menjaga kepentingan publik. Berbagai alat (tools) seperti halnya yang dimanfaatkan oleh sektor bisnis, juga dimanfaatkan oleh sektor publik agar tujuannya dapat tercapai secara lebih efektif dan efisien (Suwarno, 2008:39)

Pada organisasi sektor publik, inovasi diartikan sebagai terobosan jenis pelayanan baik yang merupakan gagasan/ ide kreatif orisinal dan/ atau adaptasi/ modifikasi yang memberikan manfaat bagi masyarakat, baik secara langsung maupun tidak langsung (Permenpan-RB No. 30 Tahun 2014). Dengan kata lain, inovasi pelayanan publik sendiri tidak mengharuskan suatu penemuan baru, tetapi dapat merupakan suatu pendekatan baru yang bersifat kontekstual dalam arti inovasi tidak terbatas dari tidak ada kemudian muncul gagasan dan praktik inovasi, tetapi dapat berupa inovasi hasil dari perluasan maupun peningkatan kualitas pada inovasi yang ada. 
Selanjutnya, PP No. 38 tahun 2017 menjelaskan bahwa inovasi daerah pada hakikatnya ditujukan untuk mendukung peningkatan kinerja pemerintah daerah dan pelayanan publik, secara optimal dalam rangka mewujudkan kesejahteraan masyarakat. Sasaran inovasi daerah diarahkan untuk mempercepat terwujudnya kesejahteraan masyarakat melalui peningkatan pelayanan publik, pemberdayaan dan peran serta masyarakat, dan peningkatan daya saing daerah.

Untuk menjalankan inovasi diperlukan pihak-pihak yang berkomitmen untuk mewujudkannya. Komitmen seluruh pihak untuk berpartisipasi aktif dan mendukung perubahan yang dilakukan, sebab kegagalan terciptanya suatu inovasi kebanyakan terjadi karena ketidakpedulian angota organisasi pada inovasi (Rediono dan Ujianto, 2013:104). Sedangkan menurut Suwarno (2008:54) menyebutkan bahwa Inovasi tidak terjadi secara mulus atau tanpa resistensi. Banyak dari kasus inovasi diantaranya justru terkendala oleh berbagai faktor, dan biasanya budaya menjadi faktor penghambat terbesar dalam mempenetrasikan sebuah inovasi.

Oleh karenanya, pada level birokrasi atau sektor publik, secara hierarki agar seluruh komponen organisasi dapat bergerak ke arah perubahan maka terlebih dahulu pimpinan organisasi perlu meletakkan kepeduliannya pada inovasi dan menjadikan inovasi sebagai budaya dalam organisasi. Sebab, Giberson (2001, dikutip Wan Ismail dan Majid, 2007:43) dalam penelitiannya menemukan bahwa para pemimpin memiliki peran yang signifikan dalam penciptaan budaya organisasi.

\section{Budaya Inovasi}

Budaya adalah kekuatan yang stabil, konservatif, dan resisten yang mungkin berubah hanya melalui intervensi manajemen (Hatch, 2004). Wieland (2004:10) dalam Didero et all (2008:8) memahami budaya inovasi sebagai lembaga (norma, nilai, formal dan informal) yang memiliki pengaruh signifikan pada bagaimana aktor yang terlibat dalam proses inovasi melihat tantangan ekonomi dan tantangan teknis lainnya, dan budaya inovasi tersebut memberikan mereka strategi untuk mengatasi berbagai tantangan tersebut.

Budaya inovasi adalah hasil dari keseluruhan interaksi multifaset antara dimensi kunci dan nilai-nilai yang tertanam dalam budaya organisasi. Nilai-nilai ini termasuk fleksibilitas, visi ke depan, pemberdayaan, apresiasi ide, toleransi resiko, komunikasi, dorongan, dan pengambilan keputusan bersama. Oleh karena itu, proses inovasi tidak akan menjadi aktivitas yang dapat dibagi, sebaliknya, harus terjadi dalam budaya yang terdiri dari seperangkat nilai yang dianut secara koheren untuk memfasilitasi praktik inovasi yang sedang berlangsung (Wan Ismail dan Majid, 2007:45)

Menanamkan budaya inovasi dalam organisasi dipandang sebagai kebutuhan vital, dan organisasi perlu menyediakan dukungan yang diperlukan untuk melancarkan proses inovasi tersebut. Dari sudut pandang praktis, mengelola inovasi penting untuk kelangsungan hidup organisasi bisnis, lembaga pemerintah maupun lembaga pengetahuan. Ini menyiratkan pada upaya memberikan karyawan kesempatan untuk mengeksplorasi dan bereksperimen, sedangkan manajemen memberikan dukungan melalui dorongan aktif atas perilaku inovatif karyawan tersebut (Wan Ismail dan Majid, 2007:38).

\section{Determinan Utama yang Mempengaruhi Budaya Inovasi}

Sebagaimana dikutip oleh Wan Ismail dan Majid (2007), Read (2000) melakukan tinjauan komprehensif dan sistematis untuk memverifikasi determinan utama inovasi yang 
sukses. Berdasarkan studinya, penentu yang paling penting adalah dukungan manajemen untuk inovasi, yaitu manajemen puncak yang memegang peranan penting dalam memberikan dukungan untuk menumbuhkan budaya inovasi. Sedangkan Chavda (2004) dalam analisis penelitiannya menunjukkan bahwa dukungan organisasi untuk inovasi dipengaruhi secara signifikan dan positif oleh dukungan manajemen, kepercayaan, penghargaan, kejelasan tujuan, dan pengorganisasian kerja tim.

Dalam penerapan budaya inovasi, gaya manajemen yang lebih partisipatif lebih disukai. Yaitu, kondisi dimana komunikasi dan kerjasama tim menjadi lebih optimal, dan dimana terdapat fleksibilitas struktural, karyawan yang diberdayakan, pengambilan risiko, dan kegagalan sesekali ditoleransi. Jika kombinasi dan penempatan yang tepat dari faktorfaktor ini di dalam organisasi, maka inovasi memiliki potensi untuk berkembang (Wan Ismail dan Majid, 2007: 41).

Untuk memelihara dan mempertahankan budaya inovasi, organisasi harus terlebih dahulu mengembangkan lingkungan yang kondusif di mana setiap anggota organisasi merasa bebas untuk berkontribusi (Beck, 2004). Organisasi membutuhkan keterbukaan, saling percaya, dorongan perilaku manajemen, orientasi strategis, struktur yang mendukung, dan pendekatan pembelajaran dan akuisisi pengetahuan. Dengan demikian, memelihara budaya inovasi pada dasarnya adalah mengenai faktor manajerial, budaya, strategi, dan struktural (Wan Ismail dan Majid, 2007:42).

Atas dasar hal tersebut, Wan Ismail dan Majid (2007) telah mengembangkan model yang holistik terkait pengembangan budaya inovasi dalam organisasi (Gambar 1) yang terdiri dari lima blok, empat yang pertama (kepemimpinan, struktur, strategi dan budaya organisasi) dianggap sebagai variabel independen, sedangkan yang kelima (budaya inovasi) mewakili variabel dependen.

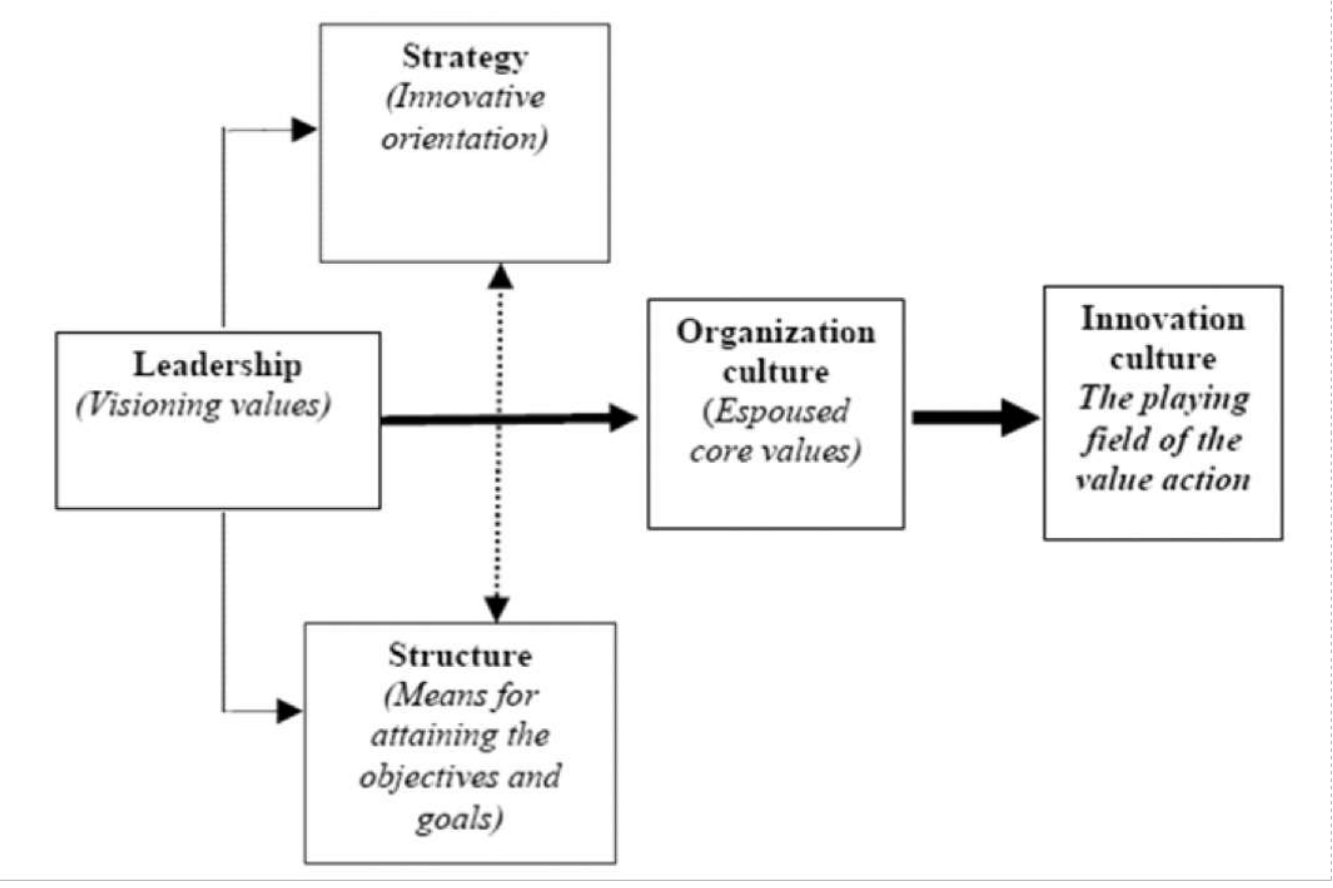

Gambar 1.

The Holistic model of Innovation Culture (Wan Ismail dan Majid, 2007:44) 
Model yang diusulkan tersebut dibangun atas (a) peran sentral para pemimpin puncak dalam mengadvokasi perubahan organisasi yang penting untuk mempertahankan potensi inovasi; (b) struktur yang mewakili metode dalam menetapkan tanggung jawab, cara organisasi berinteraksi, dan cara anggota berkomunikasi; (c) strategi yang mewakili peluang yang dapat membuka jalan untuk menciptakan dan mempertahankan budaya inovasi; dan (d) budaya organisasi sebagai sumber fitur utama dalam memelihara budaya seperti shared values, keyakinan, dan perilaku. Budaya organisasi berfungsi sebagai mediator dan dipengaruhi oleh para pemimpin untuk menghasilkan budaya inovasi. Budaya yang muncul karenanya akan menentukan bagaimana kreativitas didorong, berapa banyak risiko yang diambil, dan sejauhmana berbagi pengetahuan dan ide menjadi sebuah norma (Wan Ismail dan Majid, 2007:46)

Dalam model ini, peran kepemimpinan telah dibangun di atas premis bahwa budaya tetap stabil sampai para pemimpin bertindak untuk mengubahnya (Schein, 1990). Tindakan ini bagaimanapun, dianggap sebagai "tugas utama" untuk merumuskan strategi dan struktur untuk memfasilitasi potensi inovatif. Hasil dari tindakan ini pada gilirannya, akan menghasilkan satu set nilai inti inovatif di seluruh organisasi yang tertanam dalam budaya organisasi. Oleh karena itu, urgensi leadership sangat penting dalam menciptakan budaya yang mendukung inovasi dan tanpanya mereka tidak mungkin menciptakan budaya inovasi (Wan Ismail dan Majid, 2007:44)

\section{HASILDAN PEMBAHASAN Profil DPMPTSP Kota Samarinda}

Dinas Penanaman Modal dan Pelayanan Terpadu Satu Pintu Kota Samarinda yang disingkat menjadi DPMPTSP Kota Samarinda dibentuk sesuai dengan Peraturan Daerah Kota Samarinda Nomor 4 Tahun 2016. DPMPTSP Kota Samarinda memiliki tugas pokok melaksanakan koordinasi dan menyelenggarakan pelayanan administrasi di bidang perijinan terpadu dengan prinsip koordinasi, integrasi, sinkronisasi, simplikasi, keamanan dan kepastian.

DPMPTSP Kota Samarinda telah banyak mengembangkan aplikasi pelayanan perizinan berbasis Information Technology (IT). Dimana pengembangan aplikasi ini bertujuan untuk memudahkan masyarakat dalam pengurusan perizinan serta memudahkan badan usaha yang akan berinvestasi di Kota Samarinda. Selain itu, dengan adanya pengembangan aplikasi perizinan maka diharapkan pelayanan yang diberikan kepada masyarakat dapat lebih transparan, akuntabel dan proses penerbitan izinnya tepat waktu sesuai dengan Standar Operasional Prosedur (SOP) yang telah ditetapkan. Sehingga tata kelola pemerintahan yang baik (Good Governance) dapat terlaksana

Saat ini, DPMPTSP Kota Samarinda telah mengembangkan sistem layanan baru berupa Anjungan Perizinan Mandiri (APM) dan Tanda Tangan Elektronik khusus Kepala Dinas. Sehingga, walaupun pimpinan organisasi tidak berada di tempat maka proses ijin tetap dapat berjalan. Tujuan pengembangan sistem tersebut adalah untuk mempersingkat proses perizinan serta memangkas biaya. Dengan adanya penerapan Teknologi Informasi pada DPMPTSP Kota Samarinda maka diharapkan akan lebih memacu kerja birokrasi yang lebih efisien dan efektif, sehingga beban administrasi Pemerintah Kota Samarinda secara keseluruhan menjadi berkurang. Beberapa Teknologi Informasi pada DPMPTSP Kota Samarinda yang telah di implementasikan yakni :

1. Pelayanan Berbasis Teknologi informasi 
2. Memiliki Website perizinan ini juga menampilkan berbagai informasi perijinan yang dapat diakses secara langsung (on-line) melalui internet oleh masyarakat dan tersedianya fasilitas untuk download formulir pendaftaran.

3. Telah memiliki Model Pengarsipan secara elektronik (E-Document).

4. Telah memiliki Sistem Pelayanan yang berbasis Data Base

5. Memiliki Layanan informasi melalui (SMS Center) untuk satus report poses perizinan dan informasi yang berkaitan

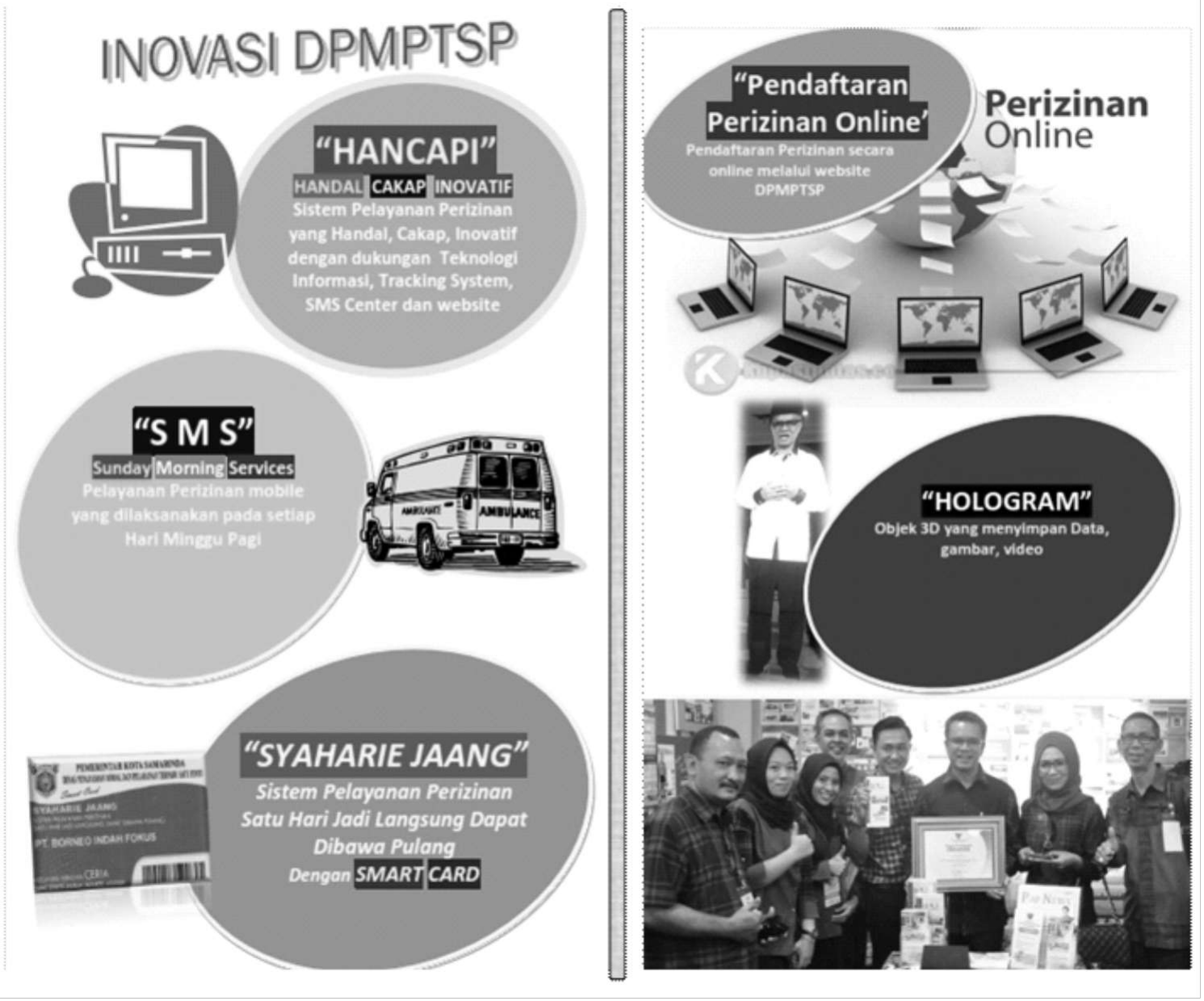

Gambar 2.

Beberapa Inovasi yang Telah Dihasilkan Oleh DPMPTSP Kota Samarinda (Sumber: Buku Profil DPMPTSP Kota Samarinda, 2018)

Selain inovasi berbasis IT, DPMPTSP Kota Samarinda juga melakukan inovasi berbasis non-IT seperti SMS (Sunday Morning Service), penerapan budaya pelayanan CERIA (Cepat, Efektif, Ramah, Inovatif, dan Amanah), menyediakan loket IKM dan pengaduan, kemudahan prosedur bertemu dan konsultasi langsung dengan pimpinan DPMPTSP Kota Samarinda, penyediaan fasilitas disabilitas, fasilitas minuman kopi gratis lengkap dengan barista-nya, fasilitas bermain anak dan ibu menyusui, serta fasilitas khusus smoking area. 
Tabel 1.

Pengukuran kinerja DPMPTSP Kota Samarinda Tahun 2015-2017

\begin{tabular}{|c|l|c|c|c|c|c|c|c|}
\hline \multirow{2}{*}{ No } & \multicolumn{1}{|c|}{ Indikator } & Satuan & \multicolumn{3}{|c|}{ Target } & \multicolumn{3}{|c|}{ Realisasi } \\
\cline { 4 - 9 } 1. & $\begin{array}{l}\text { Rasio Jumlah Proses } \\
\text { Penyelesaian Berkas Izin } \\
\text { dengan Sistem Aplikasi } \\
\text { Perizinan Berbasis IT }\end{array}$ & $\begin{array}{c}\text { Izin Terbit } \\
\text { / Hari }\end{array}$ & 55 & 55 & 55 & 56 & 50 & 50 \\
\hline 2. & $\begin{array}{l}\text { Jumlah Penerbitan Izin } \\
\text { dalam rangka Peningkatan } \\
\text { Investasi Daerah Kota } \\
\text { Samarinda }\end{array}$ & Izin Terbit & 13.200 & 13.500 & 13.600 & 14.010 & 12.420 & 10.153 \\
\hline 3. & $\begin{array}{l}\text { Prosentase Nilai Rata-Rata } \\
\text { Indeks Kepuasan } \\
\text { Masyarakat terhadap } \\
\text { Pelayanan Perizinan }\end{array}$ & $\%$ & 80 & 80 & 82 & 84,23 & 87,13 & 89,75 \\
\hline
\end{tabular}

Berdasarkan tabel 1 di atas terlihat bahwa tingkat kepuasan masyarakat terhadap pelayanan DPMPTSP Kota Samarinda terus mengalami peningkatan ditengah gencarnya berbagai inovasi yang telah dilakukan. Hal ini tentu mengindikasikan bahwa terdapat hubungan yang positif, langsung, dan relevan antara inovasi dengan tingkat kepuasan masyarakat.

\section{Apresiasi Inovasi kepada DPMPTSP Kota Samarinda}

Beberapa penghargaan dan pengakuan yang diperoleh DPMPTSP Kota Samarinda atas inovasi yang sudah dijalankan atau dihasilkan menunjukkan bahwa budaya inovatif sudah berjalan berkesinambungan di instansi tersebut. Beberapa penghargaan tersebut diantaranya:

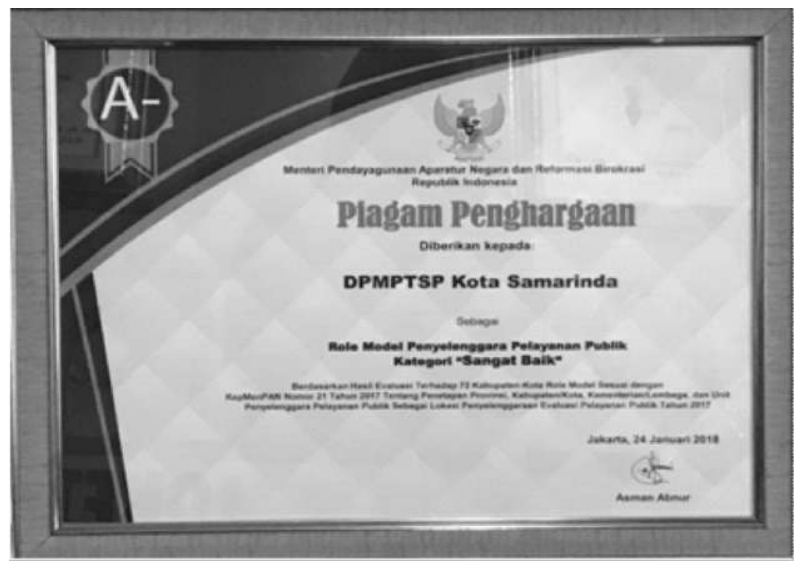

\section{PIAGAM \\ PENGHARGAAN}

SEBAGAI ROLE MODEL

PENYELENGGARA

PELAYANAN PUBLIK

KATEGORI "SANGAT

BAIK" 


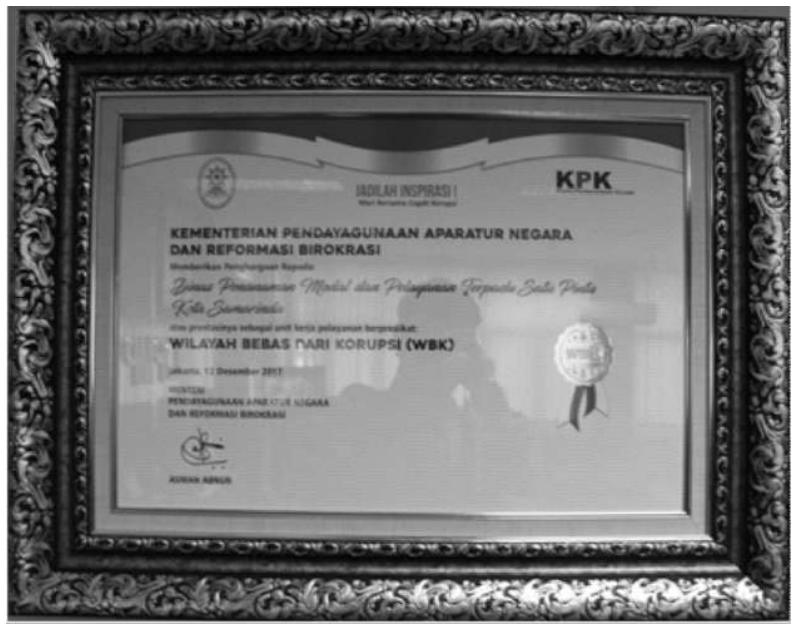

\section{PIAGAM \\ PENGHARGAAN}

SEBAGAI WILAYAH

BEBAS DARI KORUPSI

(WBK) OLEH KEMENPAN-

RB REPUBLIK

INDONESIA

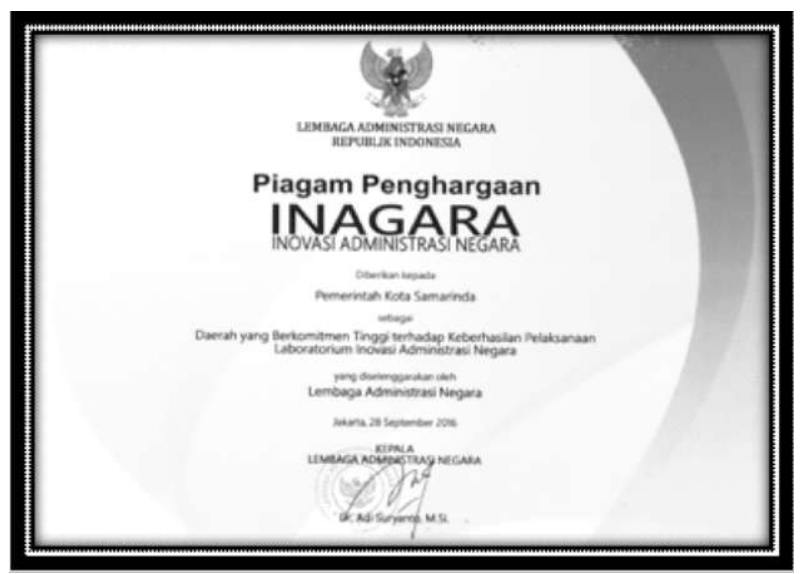

\section{PIAGAM \\ PENGHARGAAN}

INAGARA

(INOVASI ADMINISTRASI

NEGARA)

\section{Analisis Penerapan Budaya Inovasi di DPMPTSP Kota Samarinda}

Inovasi yang dihasilkan DPMPTSP Kota Samarinda jika dicermati banyak yang diadopsi atau direplikasi dari instansi lain, namun sudah dilakukan modifikasi, pembaharuan, atau pengembangan dari model inovasi sebelumnya sehingga menjadi lebih efektif, efisien, mudah, dan sesuai dengan kebutuhan DPMPTSP Kota Samarinda dan pengguna layanan. Meskipun demikian, terdapat pula inovasi-inovasi original yang dihasilkan langsung secara mandiri oleh DPMPTSP Kota Samarinda.

Berdasarkan hasil wawancara yang dilakukan, diketahui bahwa untuk menghasilkan berbagai inovasi atau pengembangan inovasi yang ada saat ini, kepala DPMPTSP Kota Samarinda membentuk suatu tim inovasi yang khusus mengelola inovasi yang akan dilakukan maupun yang sudah dilaksanakan oleh DPMPTSP Kota Samarinda. Tim inovasi tersebut dibentuk dengan menunjuk perwakilan masing-masing unit kerja di lingkungan DPMPTSP Kota Samarinda yang dianggap memiliki kemampuan merencanakan dan mengeksekusi ide atau gagasan inovasi. Pertemuan rutin untuk menggali ide-ide inovasi baru dilakukan setiap minggunya dengan dipimpin langsung oleh kepala DPMPTSP Kota Samarinda.

"Masalah inovasi saya ada tim, jadi yang masuk tim ini supaya dia fokus dengan kegiatan inovasi dan dia memang khusus sampai dengan menggodok rencananya, tim itu sebagai koordinator" (Kepala DPMPTSP Kota Samarinda, 16 Juli 2018) 
Alasan lain dibentuknya tim inovasi ini adalah kemudahan dalam bekerjasama dan berdiskusi terkait rencana inovasi yang akan dikembangkan. Tim inovasi yang dibentuk diharapkan dapat bekerjasama dengan lebih mudah karena diisi oleh para pegawai nonstruktural yang secara sukarela bekerja untuk menghasilkan inovasi tanpa diberikan honor. Namun demikian, sebagai apresiasi, pimpinan memberikan dukungan atas kebutuhan yang diperlukan seperti fasilitas, sarana dan prasarana, kemudahan akses, dan lain-lain.

Bahan utama bagi tim inovasi untuk bekerja diantaranya berdasarkan pada hasil rapat inovasi internal tim inovasi, hasil studi tiru dari instansi lain di luar daerah, juga dari rapatrapat koordinasi dengan membahas ide-ide dari pimpinan dan pegawai DPMPTSP Kota Samarinda. Dari berbagai sumber bahan kerja tersebut, kemudian diolah dan didesain rencana pelaksanaannya oleh tim inovasi yang ditunjuk. Perlu digarisbawahi bahwa setiap desain rencana inovasi tersebut selanjutnya akan diputuskan secara bersama-sama dalam rapat internal DPMPTSP serta dilaksanakan secara bersama-sama dengan memperhitungan sisi positif dan negatifnya.

Pembentukan suatu tim inovasi tentu cukup baik untuk lebih memfokuskan eksekusi terhadap suatu ide atau gagasan inovasi. Meskipun demikian, perlu diperhatikan bahwa tim inovasi akan dapat bekerja optimal jika didukung oleh pimpinan dan organisasi secara keseluruhan. Disamping itu, juga perlu dipastikan bahwa tim inovasi tersebut mampu untuk secara terbuka menampung dan mengeksekusi pula ide-ide inovasi yang berasal dari luar tim inovasi yang telah ditunjuk. Hal ini tentu sangat penting dilaksanakan agar segenap komponen pegawai dalam organisasi juga memiliki semangat untuk berinovasi serta untuk lebih memantapkan internalisasi budaya inovasi kepada seluruh pegawai dalam organisasi.

Keterbukaan pimpinan atas ide dan gagasan inovasi yang diusulkan baik oleh tim inovasi, maupun dari para pegawai sangat tinggi. Hal ini dibuktikan dengan hasil rekapitulasi pertanyaan terbuka dari 32 pegawai DPMPTSP Kota Samarinda yang keseluruhannya memberikan penjelasan bahwa respon pimpinan terhadap ide-ide inovasi yang diusulkan oleh para pegawai adalah sangat baik. Pimpinan menerima ide inovasi tersebut dan akan direspon dengan baik sejauh ide inovasi tersebut sejalan dengan visi dan misi organisasi, kemudian akan ditindaklanjuti oleh tim inovasi untuk mengeksekusinya. Lebih lanjut diperoleh pula penjelasan bahwa pegawai di DPMPTSP Kota Samarinda dapat secara bebas dan terbuka mengusulkan ide inovasi kepada pimpinan, sepanjang sesuai dengan kebutuhan dan tujuan organisasi.

Untuk inovasi-inovasi berbasis IT yang memerlukan pengetahuan dan keterampilan khusus, pimpinan biasanya mencoba untuk mencari tahu sendiri isi dari aplikasi tersebut, dan jika dibutuhkan untuk melakukan studi banding atau studi tiru atau perlu dilakukan pembelajaran langsung ke vendor atau pembuat aplikasinya maka akan segera dilakukan. Hal ini tentu menunjukkan peran serta pimpinan secara langsung dalam mendukung dan mewujudkan inovasi yang telah digagas di DPMPTSP Kota Samarinda. Selain itu, juga menunjukkan karakter pimpinan yang selalu "haus" dan terbuka terhadap perubahan, serta senang mengambil resiko, karena jika hendak berinovasi maka juga harus siap untuk gagal jika tidak berhasil.

Budaya inovasi yang berjalan di DPMPTSP Kota Samarinda telah menghasilkan banyak inovasi yang juga berimplikasi pada banyaknya penghargaan yang diperoleh. Namun demikian, kondisi ini belum mampu dicontohkan atau direplikasikan di seluruh SKPD di lingkungan Pemerintah Kota Samarinda. Budaya inovasi pada OPD lainnya relatif masih terhambat oleh budaya lama di organisasi tersebut, serta keterbukaan akan perubahan oleh pimpinan OPD tersebut yang dinilai masih rendah. Sehingga relatif OPD-OPD lainnya masih jauh tertinggal dibandingkan dengan DPMPTSP Kota Samarinda. 
"Kalo dilihat dari penghargaan yang diraih saya sering sekali tampil saya merasa tidak enak dengan teman teman SKPD lain kasian jauh tertinggal" (Kepala DPMPTSP Kota Samarinda, 16 Juli 2018)

Mengantisipasi adanya perpindahan jabatan di lingkungan Pemerintah Kota Samarinda yang dapat terjadi sewaktu-waktu dan agar inovasi di DPMPTSP Kota Samarinda tetap berkesinambungan, maka pimpinan DPMPTSP Kota Samarinda sudah mencoba untuk menyiapkan kader-kader kepemimpinan yang diharapkan bisa melanjutkan atau mempertahankan budaya inovasi yang sudah tercipta di DPMPTSP Kota Samarinda. Selain itu, pimpinan DPMPTSP Kota Samarinda juga menyadari bahwa inovasi tidak boleh hanya bergantung pada satu orang saja atau pada pimpinannya semata. Sehingga upaya membentuk SDM pegawai DPMPTSP Kota Samarinda yang inovatif serta punya jiwa kepemimpinan yang kuat menjadi suatu kebutuhan utama untuk dipersiapkan.

"Saya takutkan kalo sewaktu waktu saya dipindah inovasinya bisa bisa hilang... Rasanya riskan kalo kita tergantung inovasi ini hanya pada satu orang saja makanya itu saya mau bikin SDM yang bagus disini. Nah cara ini yang agak susah untuk di contoh teman teman di SKPD lainnya" (Kepala DPMPTSP Kota Samarinda, 16 Juli 2018)

Salah satu cara yang sering dilakukan untuk mempersiapkan kader-kader kepemimpinan inovatif tersebut adalah dengan mengajak para pegawai tersebut mengunjungi berbagai instansi di Indonesia serta menemui para pemimpin instansi di berbagai kementerian/ lembaga/ provinsi/ kabupaten/ Kota dengan harapan para pegawai tersebut dapat belajar bagaimana cara suatu instansi melayani publik, meningkatkan kepercayaan diri pegawai tersebut untuk berinovasi, serta hal-hal utama yang perlu diperlukan dalam mempercepat proses pelayanan publik.

Selain mempersiapkan kader kepemimpinan inovatif, pimpinan DPMPTSP Kota Samarinda juga seringkali mengajak OPD di lingkungan Pemerintah Kota Samarinda yang masih tertinggal dalam hal inovasi untuk belajar ke DPMPTSP Kota Samarinda, karena DPMPTSP Kota Samarinda memiliki banyak inovasi dan terbukti mendapatkan banyak penghargaan sehingga menjadi role model di Kota Samarinda. Pimpinan DPMPTSP Kota Samarinda menyadari bahwa jika hanya DPMPTSP Kota Samarinda yang terus mengalami kemajuan dalam hal inovasi maka OPD-OPD lain akan semakin tertinggal, dan dapat dipastikan kinerja Pemerintah Kota Samarinda secara keseluruhan akan dinilai tidak optimal atau rendah. Sehingga pimpinan DPMPTSP Kota Samarinda selalu mengingatkan dan mendorong OPD-OPD lain untuk berinovasi dan cara paling mudah adalah senantiasa mengajak OPD-OPD lain belajar di DPMPTSP Kota Samarinda.

Ajakan pimpinan DPMPTSP ini tentu sesuai dengan amanat yang disampaikan dalam Permenpan-RB No. 30 tahun 2017 yang menyebutkan bahwa bagi unit pelayanan publik yang sudah memiliki kondisi yang kondusif, memiliki peran dalam membangun dan menumbuhkembangkan inovasi, juga memotivasi unit pelayanan publik yang lain berbuat yang serupa walaupun harus tidak sama (perlu modifikasi). Transfer pengetahuan inovasi pelayanan publik (ide, teknologi, proses, maupun aspek managerial) dapat dengan menerapkan metode seperti technical assistant, peer to peer learning, atau field visit.

Dalam hal target inovasi, pimpinan DPMPTSP Kota Samarinda tidak memberikan target inovasi pada suatu periode tertentu, melainkan inovasi di lingkungan DPMPTSP Kota 
Samarinda terus didorong setiap saat kepada seluruh pegawai. Keterangan ini juga senada dengan hasil wawancara kepada 32 pegawai DPMPTSP yang menyebutkan bahwa DPMPTSP Kota Samarinda rutin menghasilkan inovasi karena setiap pegawainya dituntut untuk melakukan inovasi. Menurut pimpinan DPMPTSP Kota Samarinda, inovasi harus terus berjalan dan tidak boleh terputus sehingga target waktu berinovasi menjadi setiap saat. Hal utama yang menjadi bekal Pimpinan DPMPTSP Kota Samarinda selain karena karakter kepemimpinannya yang kuat adalah kemampuannya untuk memahami secara mendalam arti atau definisi sebuah inovasi. Dari hasil wawancara serta analisis terhadap jawaban dari para pegawai, diketahui bahwa pimpinan DPMPTSP Kota Samarinda memahami secara jelas bahwa inovasi tidak serta merta harus berwujud digital atau berbasis IT tetapi esensi dari sebuah budaya inovasi adalah merubah mental aparatur menjadi lebih baik, responsif, serta memiliki kemampuan berinovasi (ability to innovate).

"Ga usah membayangkan yang aneh aneh untuk berinovasi. Yang penting bisa merubah sikap merubah mental itu masuk kategori inovasi. Tujuan utama kami itu bukan untuk penghargaan tetapi tujuan kami adalah tampil sebaik-baiknya" (Kepala DPMPTSP Kota Samarinda, 16 Juli 2018)

Dapat pula dianalisis bahwa, Pimpinan DPMPTSP Kota Samarinda mendorong lahirnya inovasi di DPMPTSP Kota Samarinda dengan tujuan utama menciptakan pelayanan publik yang semakin efektif dan efisien, bukan semata-mata untuk meraih sebuah penghargaan atau pengakuan. Beliau juga seringkali mengingatkan kepada pegawai DPMPTSP Kota Samarinda untuk tidak cepat puas atas capaian yang dihasilkan namun terus melakukan perbaikan dan improvisasi agar dapat lebih baik lagi dalam menghadirkan inovasi yang semakin mempermudah publik dalam berurusan dengan DPMPTSP Kota Samarinda dan mempermudah organisasi dalam bekerja.

\section{Faktor Penentu Penerapan Budaya Inovasi di DPMPTSP Kota Samarinda}

Berdasarkan penjelasan Permenpan-RB No. 30 Tahun 2014 disebutkan bahwa tumbuhnya model pelayanan publik yang inovatif memerlukan kondisi yang kondusif, baik dari sisi pengelola unit pelayanan maupun dari sisi kepemimpinan Pemerintah Daerah yang memungkinkan kreatifitas itu tumbuh dan berkembang. Lingkungan kondusif untuk berinovasi dapat dinilai cukup berhasil diterapkan di DPMPTSP. Dari keseluruhan jawaban terbuka dari pegawai DPMPTSP Kota Samarinda menegaskan bahwa semangat berinovasi sangat tinggi karena lingkungan kerja mereka yang selalu positif, team-work yang kuat, serta kepemimpinan yang proaktif dan peduli.

Dari hasil wawancara dan analisis terhadap jawaban seluruh pegawai di DPMPTSP Kota Samarinda dapat diketahui secara jelas bahwa budaya inovasi agar efektif berjalan dalam suatu organisasi maka kunci utamanya terletak pada 4 (empat) hal penting yakni, pimpinan organisasinya, SDM yang handal, budaya kerjasama kerja yang tinggi, serta faktor dukungan anggaran. Keempat faktor ini sangat berkaitan erat dan saling menunjang satu sama lain, sehingga keempat faktor ini perlu untuk terus diperhatikan penguatannya secara berkesinambungan. 


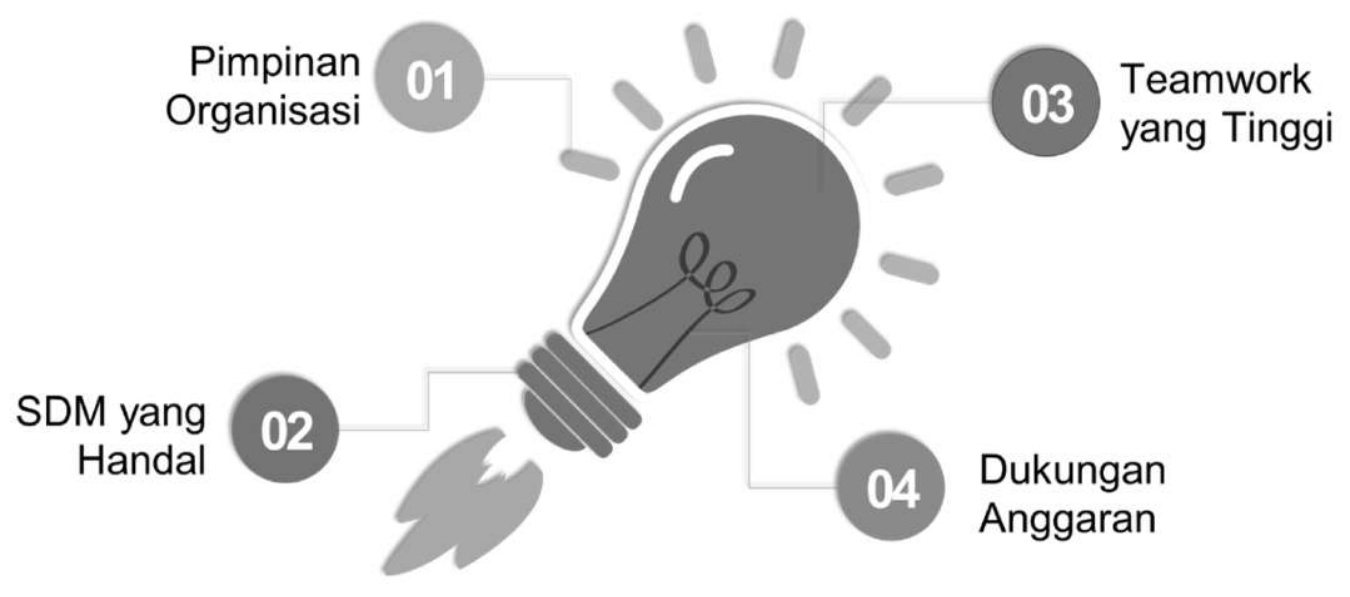

Gambar 2.

Analisis Faktor Determinan Aktualisasi Budaya Inovasi di DPMPTSP Kota Samarinda

Pimpinan organisasi yang berkomitmen terhadap inovasi, memiliki visi perubahan, berpikiran terbuka dan positif, serta mampu memberikan apresiasi tinggi atas capaian inovasi adalah karakter kepemimpinan inovatif yang sangat dibutuhkan agar budaya inovasi dapat berjalan mulus dan diinternalisasi dengan optimal oleh lingkungan organisasi. Hal ini senada dengan penelitian Trang (2013:209) yang menyebutkan bahwa kepemimpinan dan budaya organisasi memiliki hubungan yang sangat erat, karena setiap pimpinan memiliki gaya kepemimpinan yang berbeda-beda yang pada akhirnya dari situlah akan terbentuk budaya organisasi. Sehingga sering dikatakan bahwa budaya organisasi mencerminkan kepemimpinan dalam organisasi tersebut.

Hasil wawancara ke seluruh pegawai DPMPTSP menyebutkan bahwa pimpinan DPMPTSP Kota Samarinda dianggap visioner dan kreatif, berpikiran terbuka, mampu memberikan contoh, selalu memberikan kontribusi yang besar dalam setiap inovasi yang dilakukan, serta sangat gencar dalam mendorong dan memberikan semangat berinovasi kepada seluruh pegawai. Beberapa pegawai bahkan menyebutkan bahwa tanpa dukungan dari pimpinan organisasi maka inovasi tidak dapat berjalan optimal, karena bisa dikatakan pengaruhnya sangat dominan atas keberhasilan suatu inovasi.

"Budaya inovasi ini kan berarti kuncinya ada pada diri pimpinannya, saya pernah mencoba saya serahkan ke anak anak, itu tidak bisa jalan dengan baik dan mereka itu takut salah dalam menjalankan tugasnya" (Kepala DPMPTSP Kota Samarinda, 16 Juli 2018)

Faktor kunci kedua agar budaya inovasi dapat berjalan optimal dalam organisasi adalah ketersediaan SDM yang handal. Handal disini tidak hanya diartikan sebagai pegawai yang kreatif dan inovatif tetapi secara luas pada kemampuan SDM yang ada untuk menindaklanjuti dan mengeksekusi setiap gagasan inovasi yang diusulkan. Pimpinan DPMPTSP Kota Samarinda mengakui bahwa budaya inovasi tidak dapat berjalan jika tidak mendapat dukungan segenap elemen dalam organisasi khususnya para pegawai yang ada. Untuk itu, Pimpinan selalu memperhatikan kebutuhan pegawai, meningkatkan kapasitas pegawai, dan selalu memberikan apresiasi positif, menghargai, dan bangga terhadap capaian positif yang dilakukan oleh para pegawai terhadap organisasi. Bahkan, setiap bulan 
dilangsungkan pertemuan dalam format santai antara pimpinan dan seluruh pegawai DPMPTSP Kota Samarinda dalam rangka evaluasi atas kinerja organisasi secara terbuka dan transparan, serta para pegawai diberikan kebebasan untuk memberikan masukan dan koreksi.

"Saya selalu perhatian sama SDM, SDM itu tidak boleh ditinggal. Saya selalu
memberikan penghargaan buat staf saya... Setiap bulan saya lakukan evaluasi sambil
makan nasi kuning dan ngobrol santai. Dalam obrolan itu tidak ada yang kita tutup
tutupi apapun hasilnya..." (Kepala DPMPTSP Kota Samarinda, 16 Juli 2018)

Temuan dua faktor utama inovasi tersebut diatas yakni kepemimpinan dan SDM, juga dihasilkan oleh penelitian yang dilakukan oleh Mirnasasi (2013) yang menemukan bahwa faktor kunci inovasi di UPTD Terminal Purabaya adalah kepemimpinan dengan visi yang jelas dan penyiapan sumber daya manusia. Namun, berbeda pada dua faktor lainnya dimana penelitian Mirnasasi (2013) menemukan faktor pelibatan semua pihak, dan evaluasi secara rutin sebagai faktor yang cukup berpengaruh terhadap inovasi di lokus yang diteliti.

Faktor kunci ketiga agar budaya inovasi dapat berjalan optimal dalam organisasi adalah budaya kerjasama tim yang tinggi. Kerjasama yang sinergis dan saling memperkuat antara pegawai juga merupakan faktor penting untuk mengeksekusi suatu inovasi yang diputuskan. Perlunya kerjasama antara pegawai dalam implementasi inovasi ini diungkapkan oleh sebagian besar pegawai DPMPTSP dalam wawancara terbuka yang dilakukan. Adanya kerjasama tim menunjukkan bahwa setiap orang merupakan elemen penting, serta capaian keberhasilan atas hasil inovasi tersebut menjadi keberhasilan bersama-sama sebagai satu kesatuan.

Selanjutnya, faktor kunci keempat agar budaya inovasi dapat berjalan optimal dalam organisasi adalah faktor dukungan anggaran. Selama peneliti melakukan observasi atas seluruh pelaksanaan inovasi di berbagai pemerintahan daerah dan termasuk di DPMPTSP Kota Samarinda, peneliti berkesimpulan bahwa setiap inovasi pada dasarnya memang membutuhkan dukungan anggaran dalam mewujudkannya. Namun demikian, terdapat inovasi-inovasi yang membutuhkan anggaran yang minimal atau sangat kecil dan terdapat pula inovasi-inovasi lainnya yang membutuhkan anggaran yang cukup besar. Sehingga, kemampuan organisasi untuk menyediakan anggaran untuk berinovasi tersebut sangat diperlukan, namun demikian jika tidak mampu disediakan mandiri oleh organisasi maka alternatif lainnya dapat dilakukan, misalnya dengan bermitra dengan pihak swasta atau mengajak partisipasi swadaya masyarakat langsung untuk bersama-sama mewujudkan inovasi yang diluncurkan tersebut.

Faktor dukungan anggaran juga penting tidak hanya sebagai dukungan terhadap inovasi tetapi juga sebagai bahan untuk memberikan apresiasi kepada pihak-pihak yang terlibat dalam proses pelaksanaan inovasi yang dijalankan. Para pegawai DPMPTSP Kota Samarinda yang berhasil menjalankan inovasinya dan menjadi yang terbaik akan diberikan apresiasi dan bahkan rewards dari organisasi. Sehingga dukungan anggaran terkait hal ini juga penting dalam memicu kompetisi berinovasi diantara para pegawai dalam organisasi, meskipun tujuan utama berinovasi tidak untuk sekedar meraih rewards tersebut namun apresiasi dan pengakuan tetap perlu diberlakukan untuk me-maintenance kinerja yang tinggi.

Akhirnya, dari keseluruhan temuan lapangan tersebut, jika diinventarisir secara mendalam maka dapat diketahui bahwa aktualisasi budaya inovasi pada DPMPTSP Kota Samarinda pada dasarnya juga relatif telah mengakomodir penerapan model holistik budaya inovasi (Gambar 1) yang dikembangkan oleh Wan Ismail dan Majid (2007) yang meliputi kepemimpinan, struktur, strategi, budaya organisaasi, hingga tercapai budaya inovasi. 
Pada aspek kepemimpinan, pimpinan DPMPTSP dapat digambarkan memahami perlunya perubahan sesuai tuntutan publik, berani mengambil resiko atas suatu perubahan, senantiasa terbuka terhadap gagasan inovatif, mampu memberikan contoh cara berinovasi, proaktif dan berkomitmen terhadap inovasi. Selanjutnya pada komponen strategi, pimpinan DPMPTSP mampu meletakkan arah, orientasi, dan tujuan atas inovasi organisasi. Pimpinan juga senantiasa memberikan dorongan dan petunjuk untuk selalu giat dalam berinovasi. Kemudian secara struktur, pimpinan mampu meyakinkan SDM di DPMPTSP untuk tidak khawatir berinovasi karena organisasi akan memberikan dukungannya secara utuh. Mekanisme komunikasi, fleksibilitas, kerjasama tim, dan pengambilan keputusan dilakukan atau dibangun secara terbuka dan bersama-sama.

Akhirnya kreativitas dan inovasi yang sudah distimulasi oleh peran kepemimpinan serta disokong oleh strategi dan struktur yang diperlukan, maka terciptalah budaya organisasi pada organisasi DPMPTSP yang senantiasa positif sesuai nilai-nilai kepemimpinan serta dibentuk atas nilai-nilai dasar struktur dan strategi sebelumnya, sehingga mengarah pada penciptaan budaya kreatif dan inovatif yang mengandalkan nilai-nilai termasuk fleksibilitas, visi ke depan, pemberdayaan, apresiasi ide, toleransi resiko, komunikasi, dorongan, dan pengambilan keputusan bersama.

\section{E. PENUTUP}

Sebagaimana penjelasan dan uraian sebelumnya dapat disimpulkan bahwa penerapan budaya inovasi di DPMPTSP Kota Samarinda relatif sudah dapat berjalan optimal, terbukti dengan berbagai capaian dan penghargaan yang telah dihasilkan. Pimpinan dan pegawai sudah memahami arti penting inovasi dalam mendukung kinerja organisasi dan senantiasa bersama-bersama bekerja, serta saling mendukung dalam mewujudkan inovasi-inovasi yang digagas.

Dapat diketahui pula faktor-faktor yang mempengaruhi keberhasilan aktualisasi budaya inovasi di DPMPTSP Kota Samarinda utamanya adalah kepemimpinan visioner dan inovatif, sumberdaya manusia yang handal, kerjasama tim yang tinggi, dan dukungan anggaran. Selain itu, juga dapat dianalisis bahwa budaya inovasi pada organisasi ini relatif sudah menerapkan model holistik budaya inovasi.

Selanjunya, untuk menumbuhkan budaya berinovasi dalam organisasi sektor publik beberapa upaya yang dapat dilakukan dan diterapkan dalam lingkungan organisasi diantaranya adalah, (1) Pimpinan organisasi perlu untuk terus memberikan motivasi dan dorongan berinovasi kepada seluruh pegawai yang ada; (2) Meningkatkan kapasitas dan daya kreasi dan inovasi para pegawai melalui pelatihan-pelatihan kreatif, travelling bersama, hingga studi banding; (3) Meningkatkan kerjasama antar pegawai dan saling mendukung untuk berinovasi melalui upaya menumbuhkan semangat, kebebasan, kepercayaan, dan keberanian untuk berinovasi, berkreasi, dan juga menyuarakannya dalam suatu rapat/ forum inovasi; (4) Perlunya organisasi menyediakan anggaran khusus untuk mendukung pelaksanaan inovasi pegawai, serta (5) Perlunya diadakan innovation challenge setiap saat untuk merangsang munculnya ide-ide inovasi yang lebih melimpah, juga upaya memberikan apresiasi kepada pegawai-pegawai yang berinovasi.

\section{DAFTAR PUSTAKA}

Beck, C. (2004). Developing a Culture of Innovation: A Workshop in Creativity through Communication Climate. International Journal of Knowledge and Change Management. 4, 78-94. 
Chavda, A. (2004). Determinants of an Innovation Supportive Organizational Culture in Local Governments. Thesis, University of New Jersey.

Didero, Maike., Gareis, Karsten., Marques, Pedro., and Ratzke, Mirjam., with contributions from other project partners. (2008). Differences in Innovation Culture Across Europe. A Discussion Paper. February 2008

Fitriana, Diah Nur. (2014). Inovasi Pelayanan Publik BUMN (Studi Deskriptif tentang Inovasi Boarding Pass System dalam Meningkatkan Kualitas Pelayanan Kereta Api PT KAI di Stasiun Gubeng Surabaya). Jurnal kebijakan dan Manajemen Publik, 2 (1), $1-10$

Giberson, T. (2001). Transferring Leader Values: The Creation of Organizational Culture. Thesis, Wayne State University.

Han, J.K., N. Kim, and RK Srivastava. (1998). Market Orientation and Organizational Performance: Is Innovation a Missing Link? Journal of Marketing, 62 (4), 30-45

Hatch, M. (2004). New Direction in the Study of Organizational Change and Innovation Processes. New York: Oxford University Press.

Ismail, Iriani. (2008). Pengaruh Budaya Organisasi Terhadap Kepemimpinan dan Kinerja Karyawan Pemerintah Kabupaten-Kabupaten di Madura. Jurnal EKUITAS, 12 (1), 18-36

Logahan, Jerry Marcellinus., dan Aesaria, Sherley Marcheline. (2014). Budaya Organisasi dan Keterlibatan Kerja Terhadap Komitmen Organisasi Berdampak pada Kinerja Karyawan pada BTN-Ciputat. Binus Business Review, 5 (2), 551-563

Martins, E .C and Terblanche, F. (2003). Building Organizational Culture that Stimulates Creativity and Innovation. European Journal of Innovation Management. 6 (1), 64-74.

Mayangsari, Putri Ismie., Soeaidy, M. Saleh., dan Prasetyo, Wima Yudho. (2013). Inovasi PT. POS Indonesia Dalam Menjaga Eksistensi dan Daya Saing Pelayanan Publik. Jurnal Administrasi Publik(JAP), 1 (2), 248-256

Mirnasari, Rina Mei. (2013). Inovasi Pelayanan Publik UPTD Terminal PurabayaBungurasih. Jurnal Kebijakan dan Manajemen Pelayanan Publik, 1 (1), 71-84

Purba, Sukarman. (2009). Pengaruh Budaya Organisasi, Modal Intelektual, dan Perilaku Inovatif Terhadap Kinerja Pemimpin Jurusan di Universitas Negeri Medan. Jurnal KINERJA, 13 (2), 150-167

Read, A (2002). Determinants of Successful Organizational Innovation: A Review of Current Research. Journal of Management Practice. 3 (1), 95-119.

Rediyono dan Ujianto. (2013). Pengaruh Inovasi, Budaya Organisasi, dan Team Work Terhadap Kinerja Manajerial Serta Implikasinya Pada Kinerja Bank Perkreditan Rakyat di Provinsi Kalimantan Timur. Jurnal Ilmu Ekonomi \& Manajemen, 9 (2), 103119

Schein E. H. (1990). Organizational Culture. American Psychologist. 45 (2), 109-119.

Suhendra, Adi. (2017). Kesiapan Pemerintah Daerah Dalam Mewujudkan Kota Cerdas Di Bandung Dan Surabaya. Matra Pembangunan. 1 (1), 1-9

Suryo, Bhikku Dharma. (2010). Pengaruh Gaya Kepemimpinan Transformasional, Budaya Organisasi, dan Inovasi Terhadap Kinerja. Jurnal Aplikasi Manajemen, 8 (2), 391-404

Suwarno, Yogi. (2008). Inovasi di Sektor Publik. Sekolah Tinggi Ilmu Administrasi- Lembaga Administrasi Negara. Penerbit STIA-LAN Press: Bandung 
Trang, Dewi Sandy. 2013. Gaya Kepemimpinan dan Budaya Organisasi Pengaruhnya Terhadap Kinerja Karyawan (Studi pada Perwakilan BPKP Provinsi Sulawesi Utara). Jurnal EMBA, 1 (3), 208-216

Wan Ismail, Wan Khairuzzaman dan Majid, Abd. (2007). Framework of the culture of innovation : A Revisit. Jurnal Kemanusiaan bil.9, Juni 2007, 38-49

\section{Peraturan Perundang-Undangan}

UU No. 25 Tahun 2009 Tentang Pelayanan Publik

UU No. 23 Tahun 2014 Tentang Pemerintahan Daerah

PP No. 38 Tahun 2017 Tentang Inovasi Daerah

Permenpan-RB No. 30 Tahun 2014 Tentang Pedoman Inovasi Pelayanan Publik 